\title{
Distribution and origin of dissolved DNA in lakes of different trophic states
}

\author{
Waldemar Siuda ${ }^{1, *}$, Ryszard J. Chróst ${ }^{1}$, Hans Güde ${ }^{2}$ \\ ${ }^{1}$ Department of Microbial Ecology, Institute of Microbiology, University of Warsaw, ul. Karowa 18, PL-00-325 Warsaw, Poland \\ ${ }^{2}$ Institut für Seenforschung, Untere Seestr. 81, D-88081 Langenargen, Germany
}

\begin{abstract}
Concentrations and origin of dissolved DNA (dDNA) were studied in 14 lakes in the Mazurian Lake District (Northern Poland) and 7 lakes in Southern Germany during the summer stratification period. dDNA concentration varied markedly (from 0.5 to $70 \mathrm{\mu g} \mathrm{l}^{-1}$ ) in the studied lakes. We suggest that this dissolved organic matter fraction can be potentially one of the most important $\mathrm{P}$ and $\mathrm{N}$ sources for planktonic microorganisms. Laboratory experiments and field observations suggested that eukaryotic microorganisms (algae) are the most important sources of dDNA in lake water, whereas bacteria mainly decompose the dDNA pool.
\end{abstract}

KEY WORDS: Dissolved DNA - Trophic status index of lake - Algae - Bacteria Primary production . Secondary production

\section{INTRODUCTION}

The majority (>95\%) of dissolved organic matter (DOM) in aquatic environments consists of polymeric, high-molecular-weight compounds (HMWC) (Thurman 1985, Münster \& Chróst 1990). It is generally believed that the molecular weight and the size of the particles are the principal factors affecting microbial utilization of DOM (Rogers 1961, Saunders 1976, Payne 1980). Since the low-molecular-weight organic compounds (LMWC) can pass directly through the cell membranes, they are decomposed faster than HMWC and play a key role in the metabolism of aquatic microheterotrophs (Siuda et al. 1991). However, the studies carried out during the last decade made this relatively plain conceptual model more complicated. Meyer et al. (1987), Tranvik (1990) and Amon \& Benner (1994, 1996) have indicated that some HMWC may be as rapidly utilized by bacteria as LMWC. These findings lead to the conclusion that knowledge of the composition and dynamics of HMWC may be equally (or even more) significant for understanding the development and activity of microbial heterotrophic communities as well as nutrients and energy cycling in natural waters.

•E-mail: mecoluw@plearn.edu.pl
Deoxyribonucleic acid, as a constituent common to all living cells, is a component of the dissolved macromolecular fraction (HMWC) in all aquatic environments. The relative contribution of carbon contained in the dissolved deoxyribonucleic acid (dDNA) fraction to the total DOC pool is commonly low and does not exceed $0.015 \%$. Therefore the role of dDNA in the carbon cycle in a lake can probably be neglected. However, a comparison of the approximate atomic ratio of the main DNA components ( $\mathrm{C}: \mathrm{N}: \mathrm{P} \approx 10: 4: 1$; Maruyama et al. 1993) and the Redfield ratio in plankton cells (106:16:1; Harris 1986) suggests that dDNA may be an attractive source of $\mathrm{N}$ and $\mathrm{P}$ for lake microorganisms.

Ambient dDNA concentrations in aquatic environments usually vary from 10 to $40 \mathrm{\mu g} \mathrm{l}^{-1}$ (Minear 1972 , DeFlaun et al. 1987, Karl \& Bailiff 1989, Paul et al. 1989, Maruyama et al. 1993, Weinbauer et al. 1995, Siuda \& Güde 1996a) and result from a variety of biological and physicochemical processes. These processes include excretion, exudation, sloppy feeding, death and autolysis of planktonic microorganisms, enzymatic hydrolysis and sorption/desorption of dDNA by seston particles (Bailiff \& Karl 1991, Ogram et al. 1994)

Three main groups of microplankton enzymes mediate the processes of liberation of the orthophosphate 
ion from a DNA molecule: DNAses (endo- and exonucleases), alkaline phosphatase (AP) and 5'-nucleotidase (5'-PN). Literature information on turnover times calculated for dDNA and its enzymatic degradation products (i.e. nucleotides) (Paul et al. 1989. Ammerman \& Azam 1991a, Siuda \& Güde 1996b) suggests that the efficiency of DNAses is the limiting step of dDNA-P regeneration in waters. The presence of DNA hydrolyzing bacteria in aquatic environments has been known for some time (Maeda \& Taga 1973, 1981). The contribution of ather microbial sources besides bacterioplankton to overall DNAse activity is still poorly studied.

Although alkaline phosphatase is often intensively produced by both algae and bacteria during periods of orthophosphate deficiency, especially in the euphotic zone of lakes, this enzyme is probably of only minor importance in 5' -PN decomposition processes. Siuda \& Güde (1994b) found that the bacterial orthophosphate resistant enzyme 5'-PN had a much higher affinity to nucleotides than AP. Moreover, Ammerman \& Azam (1991b) and Thingstad et al. (1993) pointed out that the nucleotide pool is important in the turnover of organic phosphoesters. Considering that the amount of dDNA in aquatic ecosystems is relatively high in comparison to the other organic P compounds (Minear 1972, Mat- suda \& Maruyama 1985), one could expect that a considerable part of enzymatically regenerated $P$ in mesoand eutrophic lakes is of dDNA. origin.

The main aim of the study was to estimate the dDNA. pool in surface waters of different meso- and eutrophic lakes and to discuss the role of various microplankton constituents in the process of dDNA liberation and decomposition. Moreover, we tried to prove that dissolved DNA represents a quantitatively significant reservoir of $\mathrm{P}$ for planktonic microorganisms, and that enzymatic liberation of $\mathrm{P}$ from this source by DNAse and subsequently by $5^{\prime}$-PN can be one of the most effective ways of $P$ regeneration in lakes.

\section{METHODS}

Study area and sampling. The investigations were carried out during summer stratification periods from 1991 to 1994 in 14 Polish lakes (Mazurian Lake District, Northern Poland) and 7 lakes located in Southern Germany (Table 1). The trophic status of the studied lakes varied from mesotrophy (Lake Kuc) to advanced eutrophy (Lake Tałtowisko). Samples (3 to 6 l) were collected under non-sterile conditions into polypropylene bottles from the surface layer $(1 \mathrm{~m})$ of the pelagic zone

Table 1. Basic morphological and limnological parameters and the mean dissolved DNA (dDNA) concentrations in the studied lakes. Lakes are arranged according to increasing trophic status. PT: total phosphorus; Chl a: chlorophyll $a_{i}$ TSI: trophic status index calculated from chl a $\left(\mathrm{TSI}_{\mathrm{chl}}\right.$ a) and from PI (TSI $\left.\mathrm{PT}_{\mathrm{T}}\right)$

\begin{tabular}{|c|c|c|c|c|c|c|c|c|}
\hline \multirow[t]{2}{*}{ Lake } & \multirow{2}{*}{$\begin{array}{l}\text { Area } \\
\text { (ha) }\end{array}$} & \multicolumn{2}{|c|}{ Depth (m) } & \multirow{2}{*}{$\begin{array}{c}\text { Chl a } \\
\left(\mu \mathrm{gl} \mathrm{l}^{-1}\right)\end{array}$} & \multirow{2}{*}{$\begin{array}{c}\mathrm{PT} \\
\left(\mu \mathrm{g} \mathrm{l}^{-1}\right)\end{array}$} & \multirow{2}{*}{$\begin{array}{l}\text { dDNA } \\
\left(\mu \mathrm{gl}^{-1}\right\}\end{array}$} & \multirow[t]{2}{*}{$\mathrm{TSI}_{\mathrm{chl} \mathrm{a}}$} & \multirow[t]{2}{*}{$\mathrm{TSI}_{P T}$} \\
\hline & & Max. & Mean & & & & & \\
\hline \multicolumn{9}{|l|}{ Polish lakes } \\
\hline Kuc & 99 & 28.0 & 8.0 & 1.7 & 25.0 & 19.3 & 51 & 35 \\
\hline Majcz & 45 & 16.5 & 3.2 & 1.8 & 31.0 & 27.3 & 54 & 36 \\
\hline Łabap & 350 & 13.4 & 8.5 & 2.2 & 54.0 & 22.0 & 62 & 38 \\
\hline Kisajno & 1896 & 25.0 & 8.4 & 3.5 & 67.0 & 16.8 & 65 & 43 \\
\hline Dargin & 2680 & 37.6 & 10.6 & 3.8 & 69.0 & 17.2 & 65 & 44 \\
\hline Sniardwy & 11340 & 23.4 & 5.8 & 8.2 & 54.0 & 43.1 & 62 & 51. \\
\hline Beldany & 941 & 46.0 & 10.0 & 9.9 & 73.0 & 49.1 & 66 & 53 \\
\hline Głębokie & 47 & 34.0 & 15.0 & 10.7 & 89.0 & 22.6 & 69 & 54 \\
\hline Ryńskie & 676 & 51.0 & 13.8 & 26.5 & 122.0 & 42.6 & 73 & 63 \\
\hline Jagodne & 943 & 37.4 & 8.7 & 30.5 & 132.0 & 57.0 & 75 & 64 \\
\hline Mikołajskie & 498 & 25.9 & 11.2 & 35.1 & 63.0 & 52.0 & 64 & 65 \\
\hline Tałty & 1160 & 44.7 & 13.5 & 40.0 & 77.0 & 43.6 & 67 & 66 \\
\hline Niegocin & 2600 & 39.7 & 9.9 & 42.7 & 173.0 & 50.5 & 78 & 67 \\
\hline Taltowisko & 327 & 39.5 & 14.0 & 55.8 & 194.0 & 59.3 & 80 & 70 \\
\hline \multicolumn{9}{|l|}{ German lakes } \\
\hline Constance & 54000 & 254.0 & 90.0 & 4.6 & 28.0 & 13.4 & 52 & 45 \\
\hline Illmensee & 70 & - & - & 11.0 & 31.0 & 38.6 & 54 & 54 \\
\hline Dagersee & 33 & 12.5 & 6.2 & 14.3 & 32.5 & 25.9 & 54 & 56 \\
\hline Schleinsee & 15 & 10.0 & 5.6 & 24.0 & 121.0 & 43.1 & 61 & 62 \\
\hline Schreckensee & 30 & 11.5 & 6.4 & 25.8 & 51.3 & 42.4 & 67 & 63 \\
\hline Lengenweiler & - & - & - & 370 & 112.0 & 41.7 & 72 & 66 \\
\hline Althauser Weih & 14 & 2.8 & 1.3 & 88.0 & 210.0 & 35.4 & 74 & 68 \\
\hline
\end{tabular}


of the studied lakes. In addition, similar samples were taken from various depths of Lake Constance and Lake Schleinsee to study the dDNA depth profiles.

dDNA determination. Lake water samples were filtered through $0.2 \mu \mathrm{m}$ polycarbonate membrane filters (Nuclepore) within 1 to $3 \mathrm{~h}$ after sampling and divided into four 0.1 to $1.0 \mathrm{l}$ subsamples. Three of them were replicates, the fourth one was supplemented with DNA from calf thymus (Serva, Cat. No. A18560) to $50-100 \mathrm{\mu g} \mathrm{l}^{-1}$ final concentration and treated in parallel to replicates for internal standardization of the measurement.

dDNA was precipitated by slow addition of CTAB (cetyltrimethyl-ammonium bromide, Sigma Chemical Co.) stock solution ( $2 \mathrm{ml}$ for each $100 \mathrm{ml}$ of sample) to stirred filtrates. Filtrates treated with CTAB were frozen at $-28^{\circ} \mathrm{C}$ and stored (no longer than $2 \mathrm{wk}$ ) for further analysis. The CTAB stock solution contained $5 \mathrm{~g} \mathrm{CTAB}$ in $1000 \mathrm{ml}$ of $0.5 \mathrm{M} \mathrm{NaCl}$. Immediately before the dDNA assay, frozen subsamples were thawed at room temperature and the insoluble DNACTA precipitate was collected by centrifugation (3400 $\times g, 30 \mathrm{~min}$ ). The DNA-CTA complex was converted into soluble DNA-Na $\mathrm{Na}_{2}$ salts by solubilizing the precipitate in $10 \mathrm{ml}$ of $1 \mathrm{M} \mathrm{NaCl}\left(3 \mathrm{~h}\right.$ at $\left.40^{\circ} \mathrm{C}\right)$. After solubilization, the dissolved DNA was separated from insoluble contaminants by additional centrifugation $(3000 \times$ g, $15 \mathrm{~min}$ ). Finally, we added $0.1 \mathrm{ml}$ of $1 \mathrm{M}$ Tris-Na buffer $(\mathrm{pH} 8.3)$ and $0.1 \mathrm{ml}\left(10 \mu \mathrm{g} \mathrm{ml}^{-1}\right)$ of DAPI (diamidino-phenyl-indole, Serva $\mathrm{GmbH}$ ) to $2.3 \mathrm{ml}$ of clear supernatant solution and after $10 \mathrm{~min}$ incubation in the darkness the fluorescence of the DNA-DAPI complex was measured with a Perkin Elmer Spectro-Fluorimeter LS 50 B or Shimadzu RF 1501 at $365 \mathrm{~nm}$ (excitation) and $445 \mathrm{~nm}$ (emission). After subtraction of the autofluorescence of DAPI free samples (DeFlaun et al. 1986), dDNA concentrations were calculated from a standard curve, taking precipitation efficiency into consideration (Karl \& Bailiff 1989).

Stock solutions (1 $\left.\mathrm{mg} \mathrm{ml}^{-1}\right)$ of DAPI and DNA from calf thymus were prepared in deionized water and stored at $-28^{\circ} \mathrm{C}$ for no longer than $1 \mathrm{mo}$. They were thawed at room temperature and diluted with deionized water to required concentrations just before the DNA assay. All DNA solutions for standard curves were prepared in $1 \mathrm{~N} \mathrm{NaCl}$. Further details of the dDNA assay are given by Siuda \& Güde (1996a).

DNAse activity. Triplicate water samples $(19.5 \mathrm{ml})$ were supplemented with $0.2 \mathrm{ml}$ of calf thymus DNA

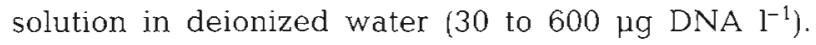
Sodium azide solution $(0.3 \mathrm{ml}$; final concentration $0.3 \%$ ) was added to prevent bacterial growth. At time 0 and after 24 to $48 \mathrm{~h}$ of incubation, $10 \mathrm{ml}$ subsamples were filtered through $0.2 \mu \mathrm{m}$ Nuclepore filters. DNA was determined directly (without precipitation) in all filtrates by the method described above. Hydrolysis rates $(v)$ for each DNA concentration were expressed as a decrease of DNA concentration in filtrates per liter and hour. The maximal ambient dDNA hydrolysis rate $\left(v_{\text {max }}\right)$ for each analysed water sample was calculated from DNA hydrolysis kinetics curves (see 'Results' and Fig. 5b) using the non-linear regression analysis software 'Enzfitter' (Elsevier Biosoft, UK).

Other analyses. Algal primary production and extracellular release of photosynthetic products were measured with the ${ }^{14} \mathrm{C}$ method (Siuda et al. 1991). Bacterial secondary production was determined by the ${ }^{3} \mathrm{H}$ thymidine method according to Chróst et al. (1988). Bacteria were counted directly in epifluorescence microscope after staining (5 min) with di-amidinophenyl-indole (DAPI) at $2.7 \times 10^{-3} \mu \mathrm{M}$ final concentration (Güde et al. 1985). Algal pigments (chl a and pheophytin) were determined spectrophotometrically, after extraction with $90 \%$ acetone (Golterman \& Clymo 1969) in German lakes or with $96 \%$ ethanol according to Marker et al. (1980) in Polish lakes. Total and dissolved organic phosphorus was measured according to Koroleff (1983).

\section{RESULTS}

\section{Concentrations of dDNA in lake water}

dDNA concentration in the surface layer of all studied lakes varied between 0.5 and $88 \mu \mathrm{g} \mathrm{l}^{-1}$ during the summer stratification period. Usually, the smallest. amounts of dDNA (up to $20 \mu \mathrm{g} \mathrm{l}^{-1}$ ) were found in mesotrophic lakes (Dargin, Kisajno, Kuc, Constance and Dagersee). Medium (20 to $40 \mathrm{\mu g} \mathrm{l}^{-1}$ ) and highest (40 to $60 \mu \mathrm{g} \mathrm{l}^{-1}$ ) dDNA contents were observed in eutrophic lakes (Table 1).

Calculations made for all the obtained results (Table 2) showed that the mean size of the dDNA pool correlated well with the trophic status index of lakes $\left(T_{S I_{P T}}: \mathrm{r}=0.62, \mathrm{n}=21, \mathrm{p}<0.01 \mathrm{TSI}_{\mathrm{chl}}: \mathrm{r}=0.79, \mathrm{n}=21\right.$, $p<0.01$ ) as well as with the Secchi disc visibility ( $r=$ $0.74, \mathrm{n}=24, \mathrm{p}<0.01$ ). Only between dDNA and basic algal parameters (i.e. chl a + pheophytin concentration and total primary production) were positive and statistically significant correlations found $(r=0.74, \mathrm{n}=21$, $p<0.01$ and $r=0.78, n=22, p<0.01$, respectively). No statistically significant correlation of dDNA with bacterial number and secondary production was observed (Table $2 ; \mathrm{r}=0.32, \mathrm{n}=35$ and $\mathrm{r}=0.39, \mathrm{n}=22$, respectively).

Changes of dDNA concentrations and basic biological parameters (chl a, bacterial number and DNAse activity) were examined more extensively in mesotrophic Lake Constance and eutrophic Lake Schlein- 
Table 2. Correlation of dDNA concentrations with basic limnological and biologial parameters in surface water of the studied lakes. Correlations and regressions $( \pm S D)$ were calculated from individual pairs of the data collected during summer periods 1991 to 1994 . ns: nonsignificant

\begin{tabular}{|c|c|c|c|c|c|}
\hline \multirow[t]{2}{*}{ Correlated parameter } & \multirow[t]{2}{*}{$\mathrm{r}$} & \multirow[t]{2}{*}{$\mathrm{n}$} & \multirow[t]{2}{*}{$\mathrm{p}$} & \multicolumn{2}{|c|}{ Linear regression } \\
\hline & & & & Slope & Constant \\
\hline Log (Secchi disc visibility) & 0.74 & 24 & $<0.01$ & $\begin{array}{c}-40.4418 \\
\pm 7.901\end{array}$ & $\begin{array}{c}48.3281 \\
\pm 11.9354\end{array}$ \\
\hline $\operatorname{TSI}_{p ;}{ }^{a}$ & 0.62 & 21 & $<0.01$ & $\begin{array}{c}1.0191 \\
\pm 0.2945\end{array}$ & $\begin{array}{l}-29.9179 \\
\pm 11.3154\end{array}$ \\
\hline $\operatorname{TSI}_{\text {chl } a} \mathrm{~b}$ & 0.79 & 21 & $<0.01$ & $\begin{array}{r}17.6587 \\
\pm 8.9469\end{array}$ & $\begin{array}{c}0.9748 \\
\pm 0.1764\end{array}$ \\
\hline $\log (\operatorname{chl} a+$ pheo. $)$ & 0.74 & 21 & $<0.01$ & $\begin{array}{l}27.5063 \\
\pm 4.0245\end{array}$ & $\begin{array}{c}1.1656 \\
\pm 0.5514\end{array}$ \\
\hline Log(total primary production) ${ }^{b}$ & 0.78 & 22 & $<0.01$ & $\begin{array}{c}0.5032 \\
\pm 0.0900\end{array}$ & $\begin{array}{c}15.9310 \\
\pm 11.5087\end{array}$ \\
\hline Bacterial number & 0.32 & 35 & ns & - & - \\
\hline Bacterial secondary production & 0.39 & 22 & ns & - & - \\
\hline
\end{tabular}

variations and maxima at $2,10,20$ and $30 \mathrm{~m}$ depth (17 to $19 \mu \mathrm{g} \mathrm{l}^{-1}$ ) in November and at 2 and $4 \mathrm{~m}$ depth 19.0 to $11.3 \mathrm{\mu g} \mathrm{l}^{-1}$ ) in December. dDNA concentrations were relatively constant in the deeper parts of the lake with minimal values below $150 \mathrm{~m}$ depth $(11.9$ and $3.4 \mu \mathrm{g} \mathrm{l}^{-1}$, respectively).

In Lake Schleinsee we found 2 dDNA maxima (Fig. 3). The first in the epilimnion ( 1 to $2 \mathrm{~m}, 47$ to $58 \mu \mathrm{g} \mathrm{l}^{-1}$ ) and the second $\left(55.6\right.$ to $\left.60.8 \mu \mathrm{g} \mathrm{l}^{-1}\right)$ in the anoxic, $\mathrm{H}_{2} \mathrm{~S}$ rich zone above the bottom sediments ( 1 to $1.5 \mathrm{~m}$ from the bottom). The dDNA concentration was negatively correlated with bacterial numbers ( $\mathrm{r}=-0.87, \mathrm{n}=5$, nonsignificant) in the surface waters (0 to $4 \mathrm{~m}$ ), but positively in the profundal zone (5 to $10 \mathrm{~m})(\mathrm{r}=0.94, \mathrm{n}=5, \mathrm{p}<0.05)$.

Our laboratory and field observations of dDNA degradation by lake microorganisms showed that bacteria can effectively utilize calf thymus

see. In surface waters (1 $\mathrm{m}$ depth) of Lake Constance (Fig. 1) the lowest amounts of dDNA (below $5 \mu \mathrm{g} \mathrm{l}^{-1}$ ) were observed at the beginning of June during the clear water phase (chl a conc. 1.3 to $5.7 \mu \mathrm{g} \mathrm{l}^{-1}$ ). In July and in the first half of August, dDNA concentrations were nearly stable (10 to $\left.15 \mu \mathrm{g} \mathrm{l}^{-1}\right)$ and reached a maximum (22 $\mathrm{Hg} \mathrm{l}^{-1}$ ) after the first phytoplankton bloom (chl a conc. $10.3 \mu \mathrm{g} \mathrm{l}^{-1}$ ). Bacterial numbers were relatively high in early summer $\left(7.7\right.$ to $23.6 \times 10^{6}$ cells $\left.\mathrm{ml}^{-1}\right)$ and decreased twice $\left(3.2\right.$ to $9.4 \times 10^{6}$ cells $\left.\mathrm{ml}^{-1}\right)$ in the second part of our investigation period.

Both dDNA depth profiles obtained for Lake Constance (Fig. 2) were similar and exhibited the greatest
DNA added to lake water samples (Fig. 4). The kinetic curves of enzymatic dDNA hydrolysis (Fig. 5) could rarely (e.g. Lake Constance, 15 June) be described by Michaelis-Menten equations. They often consisted of 2 steps (e.g. Lake Constance, 6 July) and sometimes (particularly in highly eutrophic lakes) were S-shaped (e.g. Lake Schleinsee, 14 July). Therefore, precise calculations of $K_{\mathrm{m}}$ was difficult. However, to compare the hydrolytic potential for DNA decomposition in various lake waters or microplankton size fractions, we tried to estimate experimentally $V_{\max }$ the maximal ambient dDNA hydrolysis rate, directly related neither to $V_{\max }$ nor to $V$ from Michaelis-

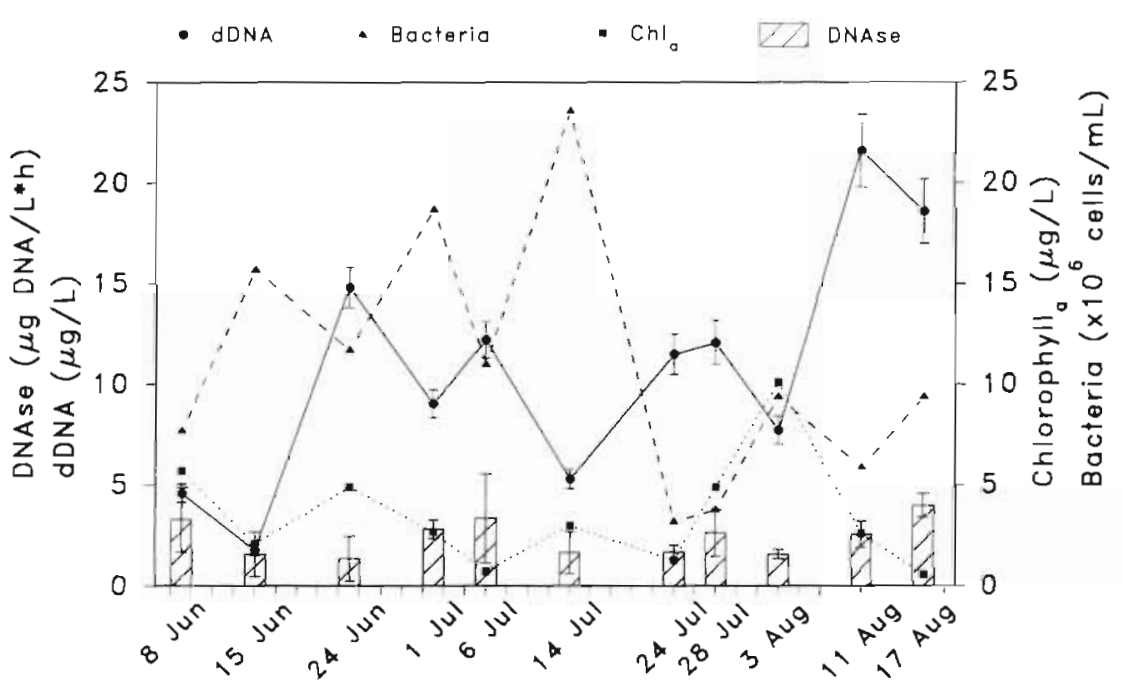

Fig. 1. Changes in dDNA concentration, bacterial number, chl a and DNAse actuvity $\left(v_{\max }\right)$ in surface waters of Lake Constance in summer 1992. Each value of dDNA concentration and DNAse activity represents a mean of triplicate determinations \pm standard error 
Fig. 2. Vertical distribution of dDNA, chl $a$ and bacteria in Lake Constance. (•) mean of triplicate determinations of $\mathrm{dDNA} \pm \mathrm{SD},(\boldsymbol{\Lambda})$ bacterial number, ( $\|$ ) chl a concentration

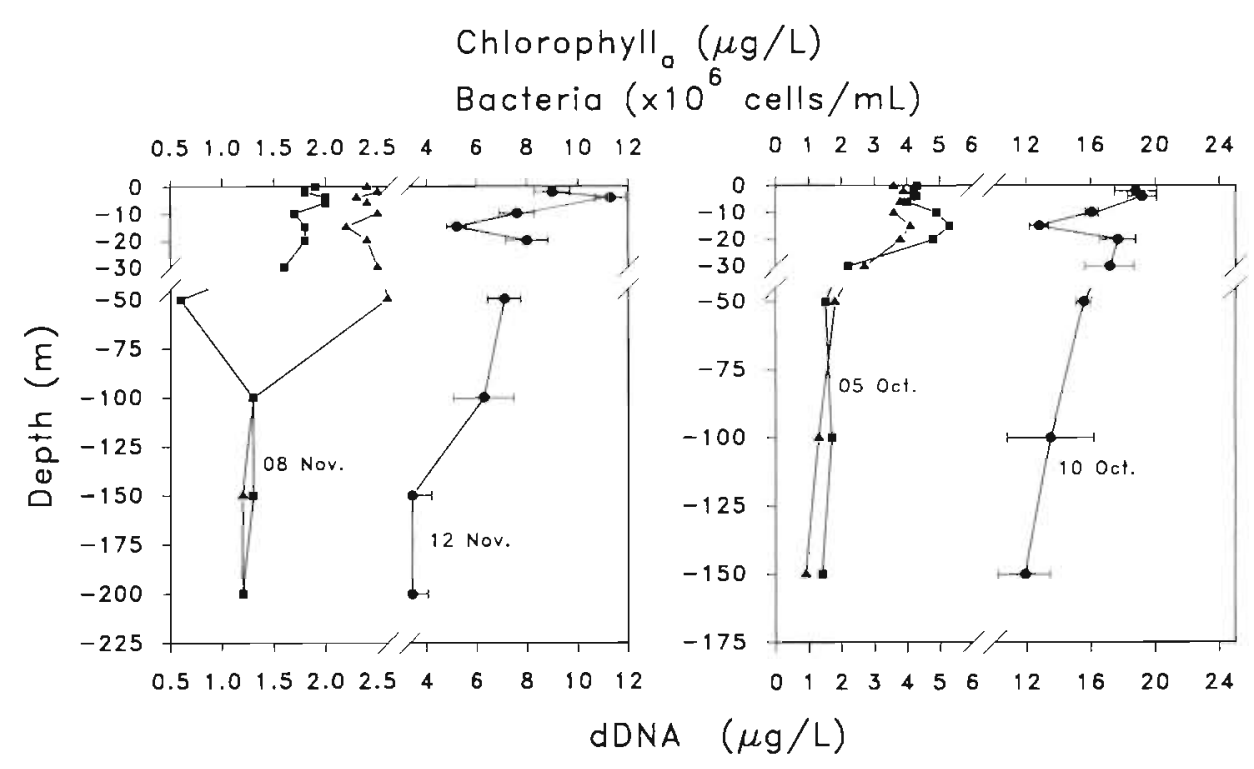

Menten equations. For this rough approximation we assumed that in the case of 2 step kinetic curves only the first 'step' describes to some extent dDNA hydrolysis at ambient dDNA concentrations. The analysis of the relationship between the $\mathrm{dDNA}$ hydrolysis rates and dDNA concentrations much higher than those observed in lake water samples has no ecological sense and may be neglected.

The ability of natural DNAses to degrade calf thymus DNA (the maximal ambient dDNA hydrolysis rate, $\left.v_{\max }\right)$ did not exhibite larger changes $(1.4$ to $4.0 \mu \mathrm{g}$ DNA $\mathrm{l}^{-1} \mathrm{~h}^{-1}$ ) in the epilimnion of Lake Constance and fluctuated around $2.5 \mu \mathrm{g} \operatorname{DNA~}^{-1} \mathrm{~h}^{-1}$ (Fig. 1), It was correlated neither with bacterial numbers nor with concentration of algal pigments.
The participation of free and cell bound DNAse to the total hydrolytic potential of the DNAse in lake water calculated for selected German and Polish lakes varied drastically from 3 to $97 \%$ (Fig. 6). Cell bound DNAse activity was mainly coupled to the picoplankton $(0.2$ to $1.0 \mu \mathrm{m})$ size fraction $(64 \%)$ whereas $33.9 \%$ of the total cell bound DNAse activity was found in the fraction $>1.0 \mu \mathrm{m}$.

\section{DISCUSSION}

Our results showed a ubiquitous distribution of dDNA in lake waters. Although the dissolved deoxyribonucleic acid concentrations in surface waters varied
Fig. 3. (a) Vertical distribution of dDNA ( $\bullet$, mean of triplicate determinations $\pm \mathrm{SD}$ ), chl a (u) and the bacteria (A) in Lake Schleinsee; (b) correlation between dDNA concentration and bacterial numbers in epilimnetic ( 0 to $4 \mathrm{~m}$, o) and profundal ( 6 to $10 \mathrm{~m}, \bullet$ ) waters of the lake
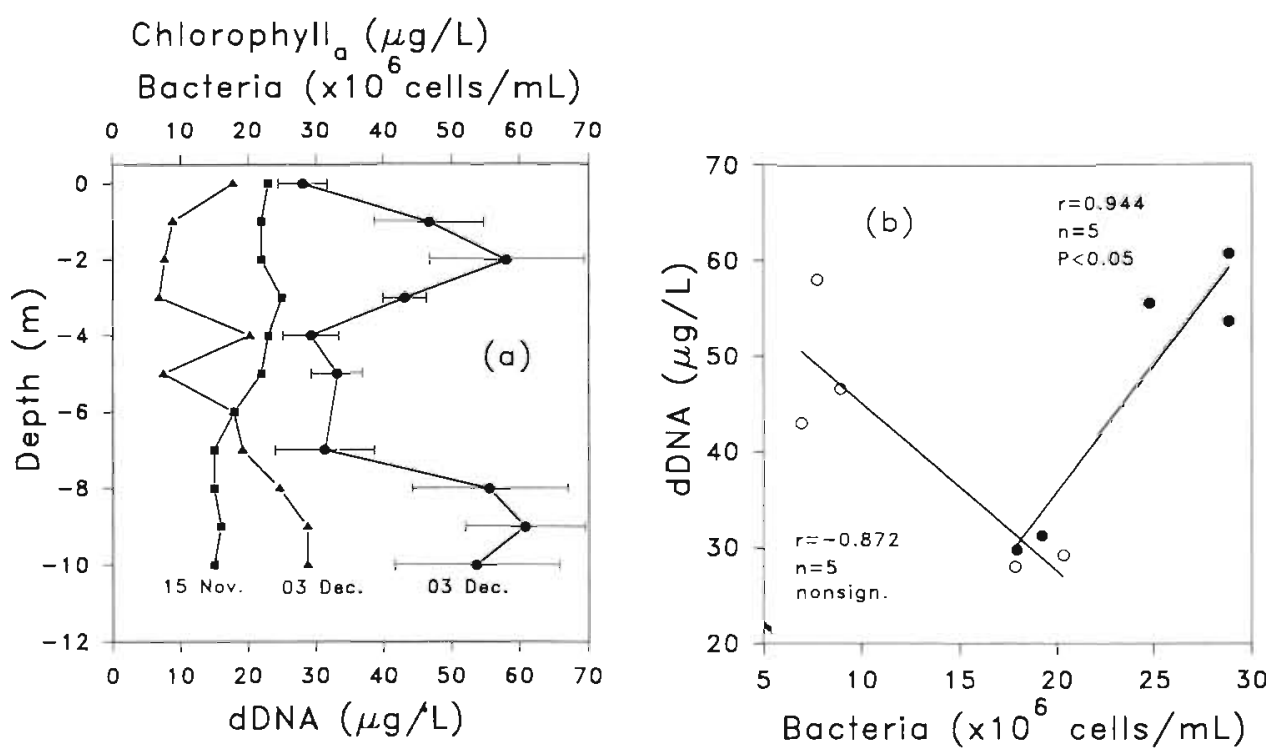


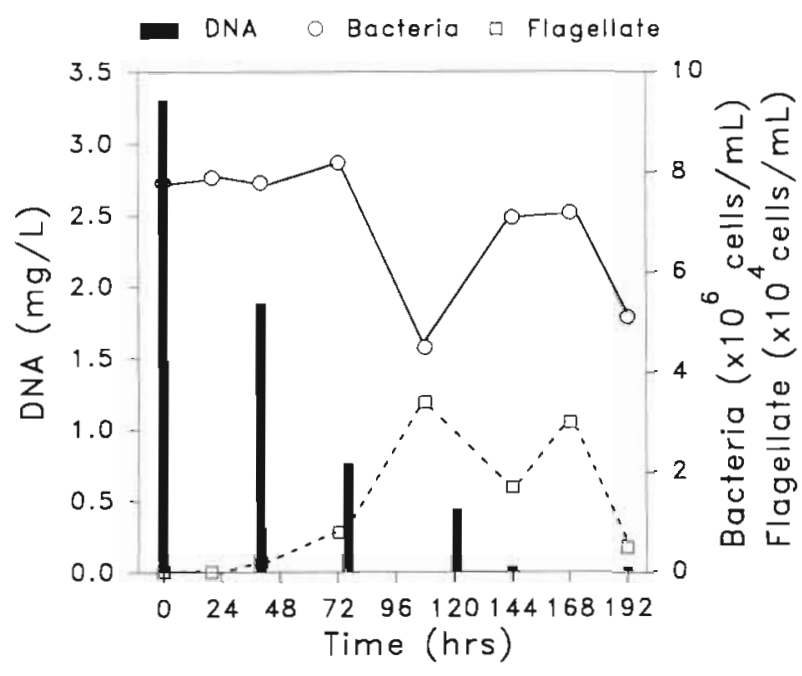

Fig. 4. DNA utilization by natural bacterial populations from Lake Constance. Surface $(1 \mathrm{~m})$ water sample was prefiltered through a $1.0 \mu \mathrm{m}$ Nuclepore membrane filter, enriched with $3 \mathrm{mg}$ of calf thymus DNA and incubated at room temperature. Flagellates in the culture developed spontaneously

among the studied lakes, with values ranging from below the detection limit $\left(0.5 \mu \mathrm{g} \mathrm{l}^{-1}\right)$ up to $88 \mu \mathrm{g} \mathrm{l}^{-1}$, the mean dDNA content did not usually exceed $20 \mathrm{\mu g} \mathrm{l}^{-1}$ in mesotrophic and $60 \mathrm{\mu g} \mathrm{l}^{-1}$ in eutrophic environments (Table 1). Since the total organic $P$ content varied from 25 to $50 \mu \mathrm{g} \mathrm{l}^{-1}$ and the range of DOP concentrations commonly changed between 5 and $15 \mu \mathrm{g} \mathrm{P} \mathrm{l}^{-1}$ in these lakes, one could estimate (presuming that DNA-P amounts for about $8 \%$ of total DNA weight) that dDNA phosphorus may contribute approximately 5 to $60 \%$ of DOP and 0.2 to $8.0 \%$ of the total P pool.

The dDNA pool was generally proportional to the Secchi disc visibility $(r=0.74, \mathrm{n}=24, \mathrm{p}<0.01)$. Therefore, one could expect also a positive correlation between dDNA and microplankton biomass as indicated by algal pigments and bacterial numbers. The role of phytoplankton in dDNA liberation processes was postulated by Minear (1972), who found considerable amounts of dDNA in pure algal cultures and a highly significant correlation of UDNA concentrations with algal pigments in the environment. Reisser et al. (1993) reported both viral and algal DNA release in Chlorella-virus cultures. Also, Beebee (1991) in his paper concluded that the bulk of dDNA in eutrophic lakes in England exists in linear rather than in circular molecules and is within the size range of eukaryotic exons. However, Paul \& Carlson (1984), Paul et al. (1987) and DeFlaun et al. (1986) questioned the significant contribution of algal DNA to the total dDNA pool and pointed out the role of bacteria in supplementing dDNA. Similarly, Turk et al. (1992) demonstrated strong evidence for the production of substantial

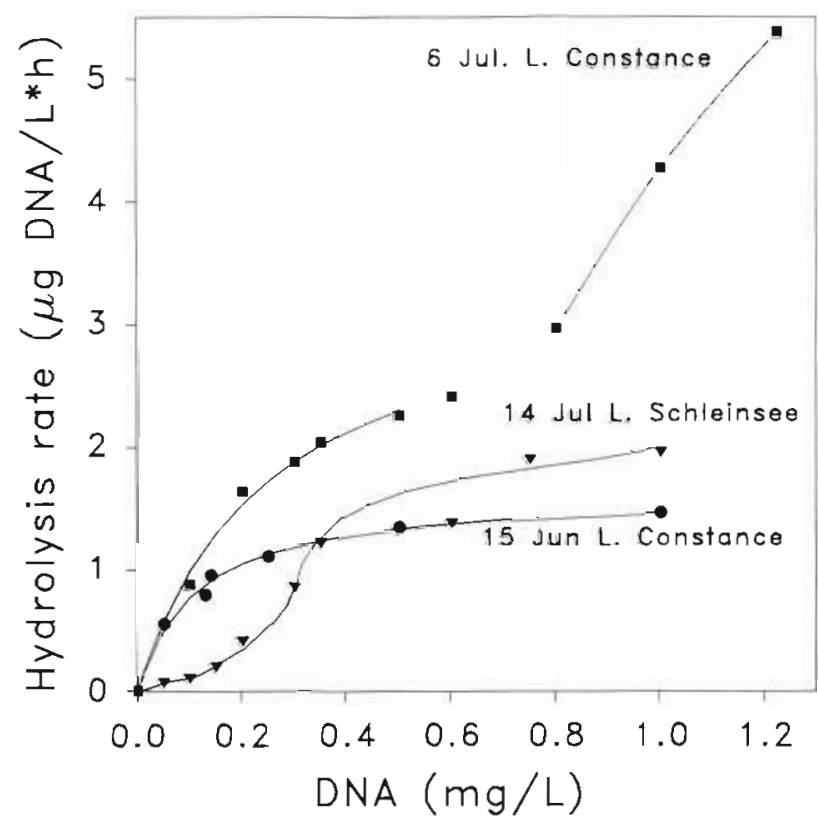

Fig. 5. Selected examples of kinetics of DNA hydrolysis by DNAses in various lake water samples

amounts of dDNA by nanoflagellate grazing on bacteria in a continuous seawater culture. Although our observations confirmed the role of phytoplankton in supplementing the dDNA pool, we could not confirm the liberation of free DNA by bacteria (Table 1, Fig. 3). The only exception was the profundal zone of the eutrophic Lake Schleinsee (Fig. 3) where a peak of dDNA concentrations (54 to $62 \mathrm{\mu g} \mathrm{l}^{-1}$ ) was correlated with relatively high bacterial numbers $(2.5$ to $2.8 \times$ $10^{7}$ cells ml ${ }^{-1}$ ). However, we speculate that in this case accumulation of dDNA in profundal waters of Lake Schleinsee could rather be an effect of intensified sedimentation of DNA rich detritus from the upper zone of the lake or/and inhibition of DNAse activity by $\mathrm{H}_{2} \mathrm{~S}$. Hoppe (1986) recognized $\mathrm{H}_{2} \mathrm{~S}$ as a noncompetitive inhibitor of several bacterial ectoenzymes (i.e. $\alpha$ - and $\beta$-glucosidase, $\quad \mathrm{N}$-acetyl-glucosaminidase, alkaline phosphatase).

Due to methodological difficulties, all results of DNAse activity measurements should be treated with great caution and may be only indirectly related to conditions of the natural environment. However, they permit one to draw some general conclusions concerning $\mathrm{P}$ regeneration processes in a lake. Firstly, free DNA is quantitatively important as a potentially available $P$ reservoir for lake microplankton. Secondly, DNAse activity in surface waters of Lake Constance was mainly extracellular or (similarly to $5^{\prime}$-nucleotidase activity) coupled to the plankton size fraction 0.2 to $1.0 \mu \mathrm{m}$, which confirms our earlier assumption that only bacteria can use dDNA as a P source (Siuda \& 
(a)

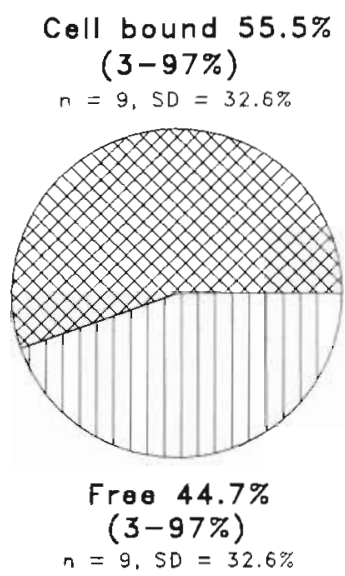

(b)

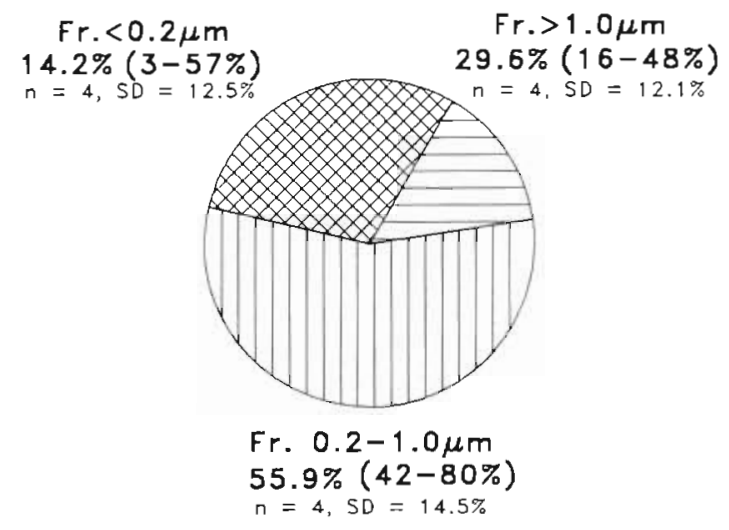

Fig. 6. (a) Mean relative contribution of free and cell bound DNAse in the lake water and (b) participation of various plankton size fractions to the total DNAse activity ( $\left.v_{\max }\right)$ in surface waters of Polish and German lakes. Ranges of values in parentheses

Güde 1996b). Thirdly, DNAse activity was relatively stable during the whole investigation period, which probably ensured constant supplementation of surface water with nucleotides. Thus, in comparison to noncontinuous phosphate liberation from qualitatively and quantitatively poorly defined phosphomonoesters by alkaline phosphatase (Taft et al. 1977, Solorzano 1978, Chróst et al. 1986, Siuda \& Güde 1994a), the more permanent regeneration of $\mathrm{P}$ from dDNA (via nucleotides and 5'-nucleotidase), although probably less efficient (Siuda \& Güde 1996b), may be regarded as one of the most important factors that favors bacterial populations in competition with algae for regenerated $P$.

Summarizing the observations made in the present study, we have found that concentrations of dDNA were related to the trophic status of the investigated lakes. Moreover, they were positively correlated with tested algal parameters (algal pigments, primary production) and did not fit to any bacterial determinants (bacterial number, secondary production, DNAse activity). Therefore we can conclude that, in surface waters of eutrophic (and perhaps mesotrophic) lakes during the summer stratification period, eukaryotic organisms (algae, zooplankton) are a source of dDNA whereas bacteria tend to utilize the dDNA pool.

Acknowledgements. This work was supported by the joint Research Project 'Cycling of matter in Lake Constance', Project BW 1203/39 University of Warsaw and Grant 6 P205 039 06 from the Polish Committee for Scientific Research. We are grateful to Lech Kufel (Hydrobiological Station Mikołajki) for information on $\mathrm{P}$ concentrations in the studied Polish lakes. The great help of all friends from the Institut fur Seenforschung (Langenargen, Germany) is also gratefully acknowledged.

\section{LITERATURE CITED}

Ammerman JW, Azam F (1991a) Bacterial 5'-nucleotidase activity in estuarine and coastal marine waters: characterization of enzyme activity. Limnol Oceanogr 36:1427-1436

Ammerman JW, Azam F (1991b) Bacterial 5'-nucleotidase activity in estuarine and coastal marine waters: role in phosphorus regeneration. Limnol Oceanogr 36:1437-1447

Amon RM, Benner R (1994) Rapid cycling of high-molecularweight dissolved organic matter in the ocean. Nature 369 : $549-552$

Amon RM, Benner R (1996) Bacterial utilization of different size classes of dissolved organic matter. Limnol Oceanogr 41:41-51

Bailiff MD, Karl DM (1991) Dissolved and particulate DNA dynamics during a spring bloom in the Antarctic Peninsula region, 1986-87. Deep Sea Res 38:1077-1095

Beebee $T$ (1991) Analysis, purification and quantification of extracellular DNA from aquatic environments. Freshwat Biol 25:525-532

Carlson RE (1977) A trophic state index for lakes. Limnol Oceanogr 22:361-369

Chrost RJ, Overbeck J, Wcisło R (1988) $\left[{ }^{3} \mathrm{H}\right]$ thymidine method for estimating bacterial growth rates and production in lake water: re-examination and methodological comments. Acta Microbiol Pol 37:95-112

Chróst RJ, Siuda W, Albrecht D, Overbeck J (1986) A method for determining enzymatically hydrolyzable phosphate (EHP) in natural waters. Limnol Oceanogr 31:662-667

DeFlaun MF, Paul JH, Davis D (1986) Simplified method for dissolved DNA determination in aquatic environments. Appl Environ Microbiol 52:654-659

DeFlaun MF, Paul JH, Jeffrey WH (1987) Distribution and molecular weight of dissolved DNA in subtropical estuarine and oceanic environments. Mar Ecol Prog Ser 38: $65-73$

Golterman HL, Clymo RS (1969) Methods for chemical analysis of fresh waters. IBP Handbook No 8, Blackwell Scientific Publications, Oxford, p 1-88

Güde H, Haibel B, Müller H (1985) Development of planktonic bacterial population in a water column of Lake Constance (Bodensee-Obersee). Arch Hydrobiol 105:59-77

Harris GP (1986) Phytoplankton ecology: structure, function and fluctuation. Chapman \& Hall, London

Hoppe HG (1986) Degradation in sea water. In: Rehm HJ, Reed G (eds) Biotechnology 8. VCH Verlagsgesellschaft, Weinheim, p 453-474 
Karl DM, Bailiff MD (1989) The measurement and distribution of dissolved nucleic acids in aquatic environments. Limnol Oceanogr 34:543-558

Koroleff $F$ (1983) Determination of phosphorus. Chemistry of the element in seawater. In: Grasshoff $\mathrm{K}$, Erhardt $\mathrm{M}$, Kremling $\mathrm{K}$ (eds) Methods of seawater analysis. Verlag Chemie, Weinheim, p 125-139

Maeda M. Taga N (1973) Deoxyribonuclease activity in seawater and sediment. Mar Biol 20:58-63

Maeda M, Taga N (1981) Fluctuation of deoxyribonuclease activity from late spring to autumn in Tokyo Bay. Hydrobiologia 76:49-55

Marker AFH, Crowther CA, Gunn RJM (1980) Methanol and acetone as solvents for estimating chlorophyll and phaeopigments by spectrophotometry. Arch Hydrobiol Beih Ergebn Limnol 14:52-69

Maruyama A, Oda M. Higashihara T (1993) Abundance of virus-sized non-DNase-digestible DNA (coated DNA) in eutrophic seawater. Appl Environ Microbiol 59:712-716

Matsuda O, Maruyama A (1985) Gel chromatographic characterization of dissolved organic phosphorus in eutrophic seawater during a phytoplankton bloom. Bull Plankton Soc Jpn 32:91-99

Meyer JL, Edwards RT, Risley R (1987) Bacterial growth on dissolved organic carbon from blackwater river. Microb Ecol 13:13-29

Minear RA (1972) Characterization of naturally occurring dissolved organophosphorus compounds. Environ Sci Technol 6:431-437

Münster U, Chróst RJ (1990) Origin, composition and microbial utilization of dissolved organic matter. In: Overbeck $J$, Chróst RJ (eds) Aquatic microbial ecology - biochemical and molecular approaches. Springer Verlag, New York, p 8-37

Ogram AV, Mathod ML, Harsh JB, Boyle J, Pettigrew CA Jr (1994) Effects of DNA polymer length on its adsorption to soils. Appl Environ Microbiol 60:393-396

Paul $\mathrm{JH}_{4}$ Carlson DJ (1984) Genetic material in the marine environment: implication for bacterial DNA. Limnol Oceanogr 29:1091-1097

Paul JH, Jeffrey WH, DeFlaun MF (1987) Dynamics of extracellular DNA in the marine environment. Appl Environ Microbiol 53:170-179

Paul JH, Jeffrey WH, David AW, DeFlaun MF, Cezares LH (1989) Turnover of extracellular DNA in eutrophic and oligotrophic freshwater environments of southwest Florida. Appl Environ Microbiol 55:1823-1828

Payne JW (1980) Transport and utilization of peptides by bacteria. In: Payne JW (ed) Microorganisms and nitrogen sources. John Wiley \& Sons, New York, p 211-256

Editorial responsibility: Karel Simek,

Ceské Budějovice, Czech Republic
Reisser W, Grein S, Krambeck C (1993) Extracellular DNA in aquatic ecosystems may in part be due to phycovirus activity. Hydrobiologia 252:199-201

Rogers HJ (1961) The dissimulation of high molecular weight organic substrates. In: Gunsalus IC, Stanier RY (eds) The Bacteria. Academic Press, New York, p 261-318

Saunders G (1976) Decomposition in fresh water. In: Anderson J. Mactayden A (eds) The role of terrestrial and aquatic organisms in decomposition processes. Blackwell, Oxford, p 341-374

Siuda W, Güde H (1994a) The role of phosphorus and organic carbon compounds in regulation of alkaline phosphatase activity and $\mathrm{P}$ regeneration processes in eutrophic lakes. Pol Arch Hydrobiol 41:171-187

Siuda W, Güde H (1994b) A comparative study on 5 '-nucleotidase (5'-nase) and alkaline phosphatase (APA) activities in two lakes. Arch Hydrobiol 131:211-229

Siuda W, Güde H (1996a) Determination of dissolved deoxyribonucleic acid concentration in lake water. Aquat Microb Ecol 11:193-202

Siuda W. Güde H (1996b) Evaluation of dissolved DNA and nucleotides as a potential sources of phosphorus for plankton organisms in Lake Constance. Arch Hydrobiol Spec Iss Adv Limnol 48:155-162

Siuda W, Wcisło R, Chróst RJ (1991) Composition and bacterial utilization of photosynthetically produced organic matter in an eutrophic lake. Arch Hydrobiol 121:473-484

Solorzano L (1978) Soluble fractions of phosphorus compounds and alkaline phosphatase activity in Loch Creran and Loch Etive, Scotland. J Exp Mar Biol Ecol 34:227-232

Taft JT, Loftus ME, Taylor WR (1977) Phosphate uptake from phosphomonoesters by phytoplankton in the Chesapeake Bay. Limnol Oceanogr 22:1012-1021

Thingstad TF, Skjoldal EV, Bohne RA (1993) Phosphorus cycling and algal-bacterial competition in Sandsfjord, western Norway. Mar Ecol Prog Ser 99: 239-259

Thurman EM (1985) Organic geochemistry of natural waters. Mauritius Nijhoff/Dr W Junk Publishers, Dordrecht

Tranvik LJ (1990) Bacterioplankton growth on fractions of dissolved organic carbon of different molecular weights from humic and clear waters. Appl Environ Microbiol 56: $1672-1677$

Turk V, Rehnstam A, Lundberg E, Hagström $\AA$ (1992) Release of bacterial DNA by marine nannoflagellates, an intermediate step in phosphorus regeneration. Appl Environ Microbiol 58:3744-3750

Weinbauer MG, Fuks D, Puškarič S, Peduzzi P (1995) Diel seasonal and depth-related variability of viruses and dissolved DNA in the northern Adriatic Sea. Microb Ecol $30: 25-41$

Submitted: March 22, 1997; Accepted: November 11, 1997

Proofs received from author(s): March 10, 1998 